\title{
Management Control Systems and Strategy Change in Buyouts
}

\author{
Hans Bruining, Marcel Bonnet, Mike Wright
}

\begin{tabular}{|l|l|}
\hline \multicolumn{2}{|l|}{ ERIM REPORT SERIES RESEARCH IN MANAGEMENT } \\
\hline ERIM Report Series reference number & ERS-2002-113-ORG \\
\hline Publication & December 2002 \\
\hline Number of pages & 37 \\
\hline Email address corresponding author & bruining@few.eur.nl \\
\hline Address & Erasmus Research Institute of Management (ERIM) \\
& Rotterdam School of Management / Faculteit Bedrijfskunde \\
& Rotterdam School of Economics / Faculteit Economische \\
& Wetenschappen \\
& Erasmus Universiteit Rotterdam \\
& P.O.Box 1738 \\
& 3000 DR Rotterdam, The Netherlands \\
& Phone: $\quad+31104081182$ \\
& Fax: $\quad+31104089640$ \\
& Email: info@erim.eur.nl \\
& Internet: $\quad$ www.erim.eur.nl \\
\hline
\end{tabular}

Bibliographic data and classifications of all the ERIM reports are also available on the ERIM website: www.erim.eur.nl 


\title{
ERASMUS RESEARCH INSTITUTE OF MANAGEMENT
}

\author{
REPORT SERIES
}

RESEARCH IN MANAGEMENT

\begin{tabular}{|c|c|c|}
\hline \multicolumn{3}{|c|}{ BIBLIOGRAPHIC DATA AND CLASSIFICATIONS } \\
\hline Abstract & \multicolumn{2}{|c|}{$\begin{array}{l}\text { The impact of management buy-outs (MBO) on strategy and management control systems } \\
\text { (MCS) is little understood. Previous research by Jones (1992) focused on efficiency-enhancing } \\
\text { buy-outs that were a feature of the early development of the market. However, MBOs are } \\
\text { heterogeneous and more recent developments have involved ownership changes that stimulate } \\
\text { entrepreneurial practices. The novel contribution of this paper is to use Simons' (1995) } \\
\text { classification of beliefs systems, boundary systems, diagnostic and interactive control systems } \\
\text { to extend Jones' study to these newer forms of MBO. Within-case analysis and cross-case } \\
\text { comparisons from four buyout firms are used to capture the interaction between management } \\
\text { control systems and competitive strategy formulation, implementation and modification. This } \\
\text { evidence supports arguments that buy-out managers undertake efforts in balancing the } \\
\text { traditional feedback systems with the newer systems that stimulate opportunity seeking and } \\
\text { learning. }\end{array}$} \\
\hline \multirow{3}{*}{$\begin{array}{l}\text { Library of Congress } \\
\text { Classification } \\
\text { (LCC) }\end{array}$} & $5001-6182$ & Business \\
\hline & $5546-5548.6$ & Office Organization and Management \\
\hline & HD 28 & Management \\
\hline \multirow{3}{*}{$\begin{array}{l}\text { Journal of Economic } \\
\text { Literature } \\
\text { (JEL) }\end{array}$} & M & Business Administration and Business Economics \\
\hline & $\begin{array}{l}\mathrm{M} 10 \\
\mathrm{~L} 2\end{array}$ & $\begin{array}{l}\text { Business Administration: general } \\
\text { Firm Objectives, Organization and Behaviour }\end{array}$ \\
\hline & L2 & Firm Objectives, Organization and Behaviour \\
\hline \multirow{3}{*}{$\begin{array}{l}\text { European Business Schools } \\
\text { Library Group } \\
\text { (EBSLG) }\end{array}$} & $85 \mathrm{~A}$ & Business General \\
\hline & $\begin{array}{l}100 B \\
240 B\end{array}$ & $\begin{array}{l}\text { Organization Theory (general) } \\
\text { Information Systems Management }\end{array}$ \\
\hline & $270 \mathrm{~L}$ & Management buy-outs \\
\hline \multicolumn{3}{|c|}{ Gemeenschappelijke Onderwerpsontsluiting (GOO) } \\
\hline \multirow[t]{3}{*}{ Classification GOO } & 85.00 & Bedrijfskunde, Organisatiekunde: algemeen \\
\hline & $\begin{array}{l}85.05 \\
85.08\end{array}$ & $\begin{array}{l}\text { Management organisatie: algemeen } \\
\text { Organisatiesociologie, organisatiepsychologie }\end{array}$ \\
\hline & 85.10 & Strategisch management \\
\hline \multirow[t]{3}{*}{ Keywords GOO } & \multicolumn{2}{|c|}{ Bedrijfskunde / Bedrijfseconomie } \\
\hline & \multicolumn{2}{|c|}{ Organisatieleer, informatietechnologie, prestatiebeoordeling } \\
\hline & \multicolumn{2}{|c|}{ Management Control Systems, strategische keuzebepaling, management buy-outs } \\
\hline Free keywords & \multicolumn{2}{|c|}{ Management Control Systems, Strategy Change, Management Buyouts } \\
\hline
\end{tabular}




\title{
Management Control Systems and Strategy Change in Buyouts
}

\author{
Hans Bruining ${ }^{1}$ and Marcel Bonnet, Rotterdam School of Economics \\ Erasmus University Rotterdam, The Netherlands \\ Mike Wright, Centre for Management Buy-out Research, \\ Nottingham University Business School
}

\footnotetext{
${ }^{1}$ Corresponding author: Hans Bruining, Associate Professor of Business \& Organisation, Rotterdam School of Economics. Address: Rotterdam School of Economics, Department Business \& Organisation, H15-26, Erasmus University, P.O.Box 1738, 3000 DR Rotterdam, The Netherlands. E-mail: bruining@few.eur.nl; Marcel Bonnet, Associate Professor of Management Accounting, Rotterdam School of Economics. Address: Rotterdam School of Economics, Department Financial \& Managerial Accounting, H14-29, Erasmus University, P.O.Box 1738, 3000 DR . Rotterdam, The Netherlands. E-mail: bonnet@few.eur.nl. Mike Wright, Nottingham University Business School, Jubilee Campus, Nottingham NG8 1BB, United Kingdom; E-mail: mike.wright@nottingham.ac.uk and Rotating Chair Organisation Studies Erasmus University Rotterdam.
} 


\title{
Management Control Systems and Strategy Change in Buyouts
}

\begin{abstract}
The impact of management buy-outs (MBO) on strategy and management control systems (MCS) is little understood. Previous research by Jones (1992) focused on efficiencyenhancing buy-outs that were a feature of the early development of the market. However, MBOs are heterogeneous and more recent developments have involved ownership changes that stimulate entrepreneurial practices. The novel contribution of this paper is to use Simons' (1995) classification of beliefs systems, boundary systems, diagnostic and interactive control systems to extend Jones' study to these newer forms of MBO. Withincase analysis and cross-case comparisons from four buyout firms are used to capture the interaction between management control systems and competitive strategy formulation, implementation and modification. This evidence supports arguments that buy-out managers undertake efforts in balancing the traditional feedback systems with the newer systems that stimulate opportunity seeking and learning.
\end{abstract}

Keywords: Management Control Systems, Strategy Change, Management Buyouts

\section{INTRODUCTION}

The rapidly growing literature on Management control systems (MCS) has tended to focus on isolated elements in organizations such as organizational design, allocation of responsibility and accountability, planning and budgeting, reward and incentive structures, information systems and performance evaluation practices (Speklé, 2001). Recognition that MCS can serve as a dialogue, learning and idea creation machine (Burchell et al., 1980) was followed by Simons' (1995) model of the dynamic relationships between MCS and strategic change (Langfield-Smith, 1997). Simons' study is an attempt to offer a coherent and comprehensive body of management control theory to which executives can turn for controlling strategy and guidance in performing their management control functions. His framework contains four levers of control that represent important variables from literature 
with clear linkage to achieve strategy, e.g. beliefs systems, boundaries systems, the traditional diagnostic control systems and interactive control systems.

In this article we use Simons' framework to extend Jones' (1992) study of management control in buy-outs. Jones (1992) shows that operational controls were altered least, but that the format and procedure for the preparation of budgets became more appropriate, indicating the use of techniques in a more relevant manner than pre-MBO. Owner-managers initiated improvements in the quality of information, intensified formal controls and introduced more disaggregated feedback to increase operational efficiency and fulfilling profit standards. Existing management accounting techniques (MAT) provided channels to enable CEOs to communicate managerial philosophies concerning the internal functioning of the independent organisation. The managerial philosophy was reflected in an increase in importance of participation in the setting of budgets after the MBO. However, Jones' findings are based on interviews with senior managers from 17 buyouts covering the period 1984 to 1985 . This first period of MBOs is strongly dominated by restructuring buyouts that take actions to protect the firm against the downside risks. New ownership and control mechanisms served as a medicine to foster efficiency. In contrast to Jones we selected venture capital backed buyouts from 1992 and 1994 that frequently take revitalization and entrepreneurial measures to exploit the upside potential of the firm (Wright et al., 2000). By selecting buy-out firms with growth perspectives and different organizational contexts than the Jones' study, we expect to find different effects concerning why and how managers change their perceptions of the role and importance of management control systems in a period of strategic (ownership) change. Otley (1999, p.365) also stresses the importance of studying management control in situations like MBOs where delayering takes place and where managers become responsible for strategy, management control and operational control as well. This article addresses the interaction between management control systems and competitive strategy formulation, implementation and modification (Atkinson et al., 1997, p.95). It examines the questions: what changes in the content and process of the firm's strategy take place after the buy-out and why and how the directors of the firm change their management control systems to implement these strategies?

The structure is as follows: after defining an $\mathrm{MBO}$ and presenting briefly the study of Jones on buyouts and accounting control systems (ACS), we describe the framework of levers of control. Then we link the MBO to the framework in order to highlight the role of buy-out management along four levers of control in relation with strategy. The research 
methodology used and data gathered are explained in the following section. From four case studies the role of the buy-out managers pre- and post-MBO are analyzed with regard to their potential to contribute to each of the four control levers. In a comparative analysis of case studies the differences in the way buy-out managers undertake management control activities are explained. The last section draws the major conclusions regarding the contribution of this article and makes comparisons with Jones' (1992) study.

\section{MANAGEMENT BUY-OUTS}

An MBO involves members of the incumbent management team acquiring a significant equity stake as individuals with institutional support in order to control the company (Robbie and Wright, 1996). The structuring of a buy-out involves the introduction of significant equity incentives for the entrepreneurs involved, together with substantial external funding and active monitoring by investors (Jensen, 1993; Wright et al., 1994) in order to control agency costs. The emphasis in buy-outs in the US has typically focused on the debt providers who provide substantial amounts of leverage. However, in Europe venture capital firms play a major role in funding buy-outs. In the UK, for example, the vast majority of buy-outs with a transaction value above $£ 5$ million involve venture capital finance (CMBOR, 2001). In the Netherlands, the value of private equity backed buy-outs amounted to $€ 4,339 \mathrm{mn}$ in 2001 (CMBOR, 2002) (Table 1).

-insert Table 1 about here-

MBOs backed by venture capital lead to significant changes in a firm's ownership composition, and can contribute to subsequent growth and changes in strategy, organisational structure and entrepreneurial practices (Reid, 1996; EVCA, 2001). Venture capital backed buy-outs may especially involve cases that are more than the organisational efficiency tools traditionally discussed in the MBO literature. Wright et al. (2000) label these buy-outs revitalisation buy-outs if they complement their efficiency focus with incremental innovations and entrepreneurial buy-outs if they combine this with strategic innovations that emerge. Extensive screening by venture capitalists at the time of investment appraisal places considerable emphasis on the entrepreneurial skills of the managers leading a proposed buy-out or buy-in (Robbie and Wright, 1995; Bruining and Wright, 2002). VCs that have a reputation to provide capital for growth, use long-term incentives to encourage process or incremental innovation by managers and show good understanding of the industry and business in the post-investment period, will attract most of these deals. These aspects of MBOs and VCs behaviour emphasise the potentially 
important interactions between MCS and strategy formulation, implementation and modification post buy-out.

\section{JONES' STUDY}

Jones (1992) focuses on changes in planning and budget techniques and operational performance controls and why and how ongoing managers change their perceptions of the role and importance of these techniques. 17 senior managers were interviewed, partly chief executives or senior financial executives and both fully conversant with ways in which ACS were used before and after the buy-out. The interviews took place two years after the incumbent management bought the firms from their parent companies and relate to the period 1984-1985. The results show positive attitudes of the employees and managers to planning and budgeting and an increase of perceived importance of these techniques, indicating a change in the way the established MAT were applied. The owner-managers improved the quality of information, intensified formal controls and introduced more disaggregated feedback to increase operational efficiency and fulfilling profit standards. Finally the study reported that CEOs used existing MATs to communicate their managerial philosophies concerning the internal functioning of the firm. The managerial philosophy was reflected in an increase in importance of participation in the setting of budgets after the MBO. Jones concluded that the independence gained by the MBO firm improved the matching between ACS and contextual variables. These findings signal pressures to improve efficiency after MBO and an increased reliance upon ACS. Existing ACS after the $\mathrm{MBO}$, are seen as channels for effecting change in organizational culture. The next section describes Simons' framework to extend the Jones' study.

\section{CONCEPTUAL FRAMEWORK: FOUR LEVERS OF CONTROL}

We agree with Atkinson et al. (1997) that management control systems must provide the stability necessary to meet users' needs efficiently, while simultaneously creating an information environment that permits managers to envision, and respond to new directions for the firm. We expect that the control needs of manager-owners in revitalization and entrepreneurial MBOs requiring product development or innovation go beyond the assistance of the ACS to achieve the financial targets agreed upon between management and investors. Careful analysis and understanding of critical performance variables is important to keep things on track, but to implement changes in strategy after an MBO effectively top management needs more than what the classical ACS provides. For example, enabling participants to interact with each other to keep the organization purpose 
clear and to convince them of the right direction, giving them ample opportunities to influence that direction. To focus on the involvement of the buy-out management in performance measurement and control to promote upside potential of the MBO firm and to protect it against downside risk, the four levers of control in the framework of Simons (1995) are used.

\section{Control Levers}

At the core of the analysis of the four levers of control is the firm's strategy (see Figure 1). This represents how the firm competes and positions itself vis-à-vis its competitors in the market. Simons argues that successful implementation of the firm's strategy depends on an understanding of certain constructs (Simons, 1995, p.6) which put into perspective that organizations are created for a purpose and that interaction among participants is needed to keep the organization's purpose clear and in harmony with the environment. A different system, or lever, the use of which has different implications, controls each construct. Each lever offers some guidance to the strategy process. These levers are:

1. Beliefs systems, used to inspire and direct the search for new opportunities; provide basic values, purpose and direction for the organization;

2. Boundary systems, used to set limits on opportunity-seeking behavior;

3. Diagnostic control systems, used to motivate, monitor, and reward achievement of specified goals;

4. Interactive control systems, used to stimulate organizational learning and the emergence of new ideas and strategies;

-insert Figure 1 about here-

The first lever reinforces seeking opportunities and the second lever selects acceptable ones in order to delineate an acceptable domain. Both control systems frame the strategic domain. Westley (1990) found evidence that middle managers will not become enthusiastic participants in the search for opportunity if they do not understand the beliefs of the organization and are not invited to participate in transforming those beliefs into actions and strategies. Simons $(1995$, p.38) concludes that beliefs are tools for articulating and 
communicating missions, credos and goals of the organization, that assist managers to transform these vague beliefs into focused activity. With respect to the second lever, the author makes a distinction between business conduct boundaries and strategic boundaries. The former imposes codes of business conduct based on society's laws, the firm's belief systems and codes of behavior promulgated by industry and professional associations. Strategic boundaries, focus on opportunity-seeking behavior to support explicit organizational strategies. Senior managers specify the range of business opportunities where they do not want to expend resources. They establish limits, based on defined business risks or desired returns before entering a market or start a business.

The last two levers aim to control the implementation and formulation of the business strategy.

The third lever introduces feedback systems to pay attention to critical performance variables in order to implement pre-set goals by taking corrective measures. Several studies label this type of ex-post monitoring, "output control" (Ouchi, 1977), "performance control" (Mintzberg, 1979), or results control (Merchant, 1985). Feedback of variance information allows adjustment of inputs or fine-tuning of the process so that future outputs will more closely match preset standards. Profit plans and budgets are the most pervasive diagnostic control systems in modern business firms.

The fourth lever focuses on interaction between participants about strategic uncertainties caused by fundamental changes in technology, competition, consumer preferences, in order to make the firm responsive, thus realizing strategy adaptations in time. Interactive control systems stimulate search and learning and allow new strategies to emerge as participants throughout the organization respond to perceived opportunities and threats. Competitive markets require organizations to break out of limited search routines (Cyert and March, 1963). To activate interactive control systems, senior management must encourage continuous search activity and create information networks inside the organization to scan and report critical changes. As Burt (1992) notes, second-hand information is often fuzzy or inaccurate, but it serves to signal something to be looked into more carefully. Interactive control systems build internal pressure to break out of narrow routines, stimulate opportunity seeking and encourage the emergence of new strategic initiatives. The common denominator for all interactive control systems according to Simons (1995, p.123) is continuous re-estimation of future states and consideration of how to react best. In general the levers of control represent important variables with a clear 
linkage to achieving strategy in routine and non-routine situations.

Figure 1 unites two opposing forces in organizations: one is aimed at expanding opportunity seeking and learning and the other at focusing on search and attention. Volberda (1998, p.103) labels these forces as exploration and exploitation and this phenomenon as the flexibility paradox for organizations. On the one hand, he argues that organizations are challenged to develop dynamic or flexible responses capabilities based on knowledge of managers and other participants who recognize quickly the need to change, experimentation and learning (Teece et al., 1997). These dynamic capabilities require dynamic control that views the capacity to change as an essential feature of sustained success. On the other hand organizations handle certain competitive changes using specialized routines for standard behavior in routine situations. According to Volberda (1998, p.109) standards provide a memory for handling routine situations and in contrast to dynamic capabilities, eliminate the need for further communication and coordination among units and positions. Cohen and Levinthal (1990) argue that the dynamic capabilities require a high absorptive capacity of management. It is critical to successful absorb signals beyond the periphery of the firm and recognise the value of new information, assimilating and applying it to commercial ends. This requires broadly scanning for new information and identifying and effectively using employees who serve as gatekeepers and boundary spanners. Both dynamic capabilities and specialized routines are recognized in the framework of Figure 1. The firm needs managers that combine the capabilities of stimulating creativity and innovation of its employees (dynamic capabilities that enhance dynamic control by using beliefs and interactive controls) with the minimisation of surprises and taking corrective actions (specialized routines that enhance static control using boundaries and diagnostic control).

In buy-outs which need at least some innovation, opportunity search and learning seem to play an important role to control the (incremental) changes in strategy. In the next section we link Simons' concept of four levers to the MBO. How these link to MBOs is discussed in the next section.

\section{LINKING MBOs TO THE FRAMEWORK}

MBOs are not just about cost reduction, low growth prospects and few investment demands as traditionally analysed (Jensen, 1989; Kaplan, 1989; Phan and Hill, 1995). Many have gone beyond efficiency incentives to become a vehicle for entrepreneurial initiatives and expansion of managerial discretion (Zahra, 1995; Bruining and Wright, 
2002). Wright et al. (2000, 2001) signal a shift from cost reduction and strategic reorientation in mature sectors to creating value in technology sectors through product development and innovation. They argue that significant entrepreneurial progress is made not through managerial incentives alone but through a cognitive shift from a managerial to an entrepreneurial mindset. Hence, there is a need to look at more different strategies and management control consequences.

In this section we develop the link between MBOs that take entrepreneurial measures and the framework of the four levers of control. We argue that this framework is useful to analyze the interrelation between the levers of control and strategy in the context of an MBO. We start with the firm's strategy and highlight the respective levers of control (see figure 1).

It is well known that managers pre-MBO typically face investment restrictions from headquarters because their firms are peripheral to the product line of the parent company (Wright et al., 2001). These restrictions reduce the scope for responding entrepreneurially to market developments. Pre-MBO, buy-out firms, if they are peripheral to the core business of the parent, may not be allowed to have growth-oriented strategies and organisations. This conflict between subsidiary management and headquarters is often an indication that a buy-out may be appropriate (Bruining, 1992, Wright et al., 2001). A significant share of MBOs divested from parent companies change to more growthoriented strategies.

Instead of obeying orders from headquarters that block innovation and investment in order to optimise goals of the diversified parent company, the buy-out managers have discretionary power to decide what is best for the business, how to organise and lead the company, and how the business plan can be carried out most profitably (Wright et al., 2001). In his research of 47 MBOs, Zahra (1995) shows that substantially investment took place in research and development, the creation of new business and product development. Therefore we expect that interactive control systems will stimulate search and learning and allow new strategies to emerge as participants throughout the organization respond to perceived opportunities and threats.

Distance between policy and implementation is also likely to become significantly shorter, because of the remarriage of ownership and control (Alchian and Demsetz, 1972). New owner-managers may show higher levels of commitment to the implementation of a growth oriented strategy than before the MBO (Zahra, 1995; Wright, et al. 2001). In turn, 
this is likely to change the organisational culture to one that is more entrepreneurially driven (Green, 1992). We expect that management will stimulate entrepreneurial initiatives that fit their vision and the firm's mission. This will make beliefs a more explicit tool for managers to provide inspiration and organizational direction for focused, purposive activity by its employees.

Top managers experience more immediate freedom and independence, which enables more flexible decision-making, more delegation, quicker action and easier consensus among manager/owners and shareholders (Bruining, 1992). This creates greater scope for autonomy. We expect delegation to produce the formulation of specific boundaries for employees post-MBO, such as return on investment, selection of product-markets and business conduct rules. This creates accountability by establishing rules and using sanctions. These boundaries will be communicated by the buy-out management to allow participants to achieve flexibility and creativity in domains with acceptable risks.

Buy-outs typically involve increased levels of external funding. The costs of servicing debt and fixed dividend commitments act as a discipline to allocate resources to operations with the strongest cash flow and eliminate unprofitable operations (Jensen, 1993; Wright et al, 1994). In addition, buy-outs are actively monitored by investors in order to control agency costs. Jones (1992) reports increases in the quality of information used for operational control, an intensification of formal controls and a more positive attitude of employees towards ACS to facilitate participation following buy-out. Similarly, in VC investments generally, Mitchell, Reid and Terry (1997) show enhanced accounting information systems are introduced at the request of financial investors, particularly with respect to monitoring reports and budgetary components. Therefore we expect that diagnostic controls will play an important role after the buy-out to achieve the financial targets agreed upon between management and investors. Using diagnostic control systems as tools of strategy implementation requires a careful analysis and understanding of critical performance variables.

By definition the incumbent management of an $\mathrm{MBO}$ takes a significant equity stake in order to control the company. The incentive compensation for the MBO managers is dependent on achieving targets for profits and turnover. Therefore, we expect an important role for diagnostic controls. Buy-outs provide not only equity incentives for managers but also control mechanisms that were previously lacking, to ensure the implementation of the ambitious growth targets of the new owners. 
These arguments suggest that post-MBO business strategy needs to be controlled in a more dynamic way. The shift from maintaining the status quo pre-MBO to acting more efficiently and entrepreneurial post-MBO, requires more organisational flexibility than before the buy-out. Dependent on the new owners' conception of the environment and perspective of the organisation-environment relationship, the firm has to develop flexibility. For example, the capability for facilitating emergent, spontaneous strategies, terminating unprofitable existing activities and developing flexible resources for effective response to (un)anticipated changes (Volberda, 1998, p.43). This suggestion fits with the central idea of the framework in Fig.1.

In order to address these control lever issues discussed above, the study examines the questions: what changes in the content and process of the firm's strategy take place after the buy-out and why and how does the management change their management control systems to implement these strategies? Answers to these questions are compared with the study of Jones. The next section explains the research methodology and data gathering process adopted in the study.

\section{METHODOLOGY AND DATA GATHERING}

We use case studies to apply Simons' approach to the interaction between strategy and management control in buy-out situations. The cases can be seen as specification case studies (Keating, 1995), to get a better view of the interaction between post buy-out strategies and management control. The empirical evidence is based on four detailed case studies. Face-to-face interviews with the CEOs, the CFOs and Directors of Production, all involved in the buy-out, were carried out during 1998 and 1999. The interviews contained semi-structured questions in retrospective about the content and the formulation of the strategy and the applied levers of control pre- and post-MBO (see Appendix 1).These questions were developed from the existing literature relating to buy-outs and control (Green, 1992; Jones, 1992; Simons, 1995 and Wright et al., 2000). The questions referred to two years before and two years after the MBO. The MBOs had 120-350 employees at the time of the buy-out and came from different vendor sources. They were selected to show different efforts to increase product innovation post-MBO. The first firm is a privatization buy-out of a governmental owned agency supplying paramedical advise, orthopedic and rehabilitation products to individuals with a physical functional limitation for lodging, working and living. The second firm is a managers-investor's buy-out (MAINBO) of a division from a foreign parent company, which manufactures and sells 
synthetic packaging for the consumer market in the food sector. The third firm is a management buy-out (MBO) from a local parent company, which went into receivership. The buy-out firm manufactures Computer Aided Design (CAD) and Computer Aided Manufacturing (CAM) systems that creates one-stop solutions for the carpet industry, printed textiles and woven fabrics industries. Besides this activity the firm is also a producer of Geographic Information Systems for municipalities. All three are venture capital backed. The fourth case study represents a shareholder repurchase of a bus company by the founders (management buy-in). For a brief description of the buy-out firms see Appendix 2.

Using the typology of Wright et al. (2000) Companies 1 and 3 can be identified as entrepreneurial buy-outs fostering strategic innovation and entrepreneurial cognition. Strategic innovation emerges because high-powered incentives and discretion are given to owner/managers. Company 1 is the first to business to sell their method for reintegrating handicapped persons to employers and their approach to recycling orthopedic and rehabilitation products. Company 3 shows its innovativeness by improving communication, networking and multi-media solutions in computer graphics technology and textile technology. Company 2 and 4 are revitalization buy-outs involved in process and incremental, imitation innovations, which complement an efficiency focus. Company 2 has built on the one stop- shop business concept for packaging in the food sector in addition to its efficiency focus. Company 4 has selected subsidized market segments and customization of the bus manufacturing process, e.g. fuel usage, choice of material, number of seats and wheel suspension in addition to its labor and material cost transparent bus manufacturing process.

Coupled with within-case analysis cross-case comparisons were carried out. Using information from these four distinct cases highlights the role of the levers more transparently. Applying the framework in a variety of buy-outs, enables us to verify the relationships in the framework in a way that contributes to development of management control theory (Eisenhardt, 1989). Choosing these buy-outs from the period 1992-1994 allowed sufficient time for the operational, organizational and strategic consequences of the change in ownership to be implemented. Three of the four firms were venture capital backed, but all set targets to grow internally from entrepreneurial measures such as incremental innovation and externally from acquisitions and or alliances.

The operationalisation of the variables in the control levers framework was based on 
the measures used by Simons (1995). Other sources of information used included business plans, annual reports and press articles. In one of the cases a stock exchange prospectus was available. Interviews were conducted with all three managers to triangulate views about changes in strategy content and strategy formulation as well as in management control activities (Eisenhardt, 1989). Full write-ups of the company studies were sent for comments to the respondents. This approach was adopted as a more appropriate instrument for capturing the complexity of the strategy and management control changes taking place following the transfer of ownership (Greene, 1992) than would be possible by a survey.

\section{CASE STUDY RESULTS}

The respective sources of the buy-outs vary, but all share pre-MBO a common lack of investments for innovation and renewal purposes. The health care privatization of Company 1 transferred its activities from a task for government to a more commercial private sector focus. Companies 2 and 3 were not central strategically to their parents and were divested by a management and investors buy-out and a management buy-out, respectively. Company 4 is a management buy-in from receivership, indicating that the core activity is not viable and thus in need of drastic change to make it commercially viable. Using within and cross-case analysis, we report below the changes in strategy content and strategy process as well as the related changes in the control levers. In Appendix 3 we summarize the key findings for each buyout.

\section{Strategy}

The content of strategy following the buy-out in all case studies shows a sharp increase in market and/or product focus. Next to internal growth, all four firms use external vehicles for growth post-MBO, such as international acquisitions in Companies 1, 2 and 3 or international alliances with customers or firms as in Companies 2 and 4.

Company 1 shows a transformation from a monopolistic supplier of wheelchairs to a market-oriented competitor in the fast growing market for healthcare services and equipment. It acquired a number of similar operations throughout Holland and soon after the MBO it provided a full service package of equipment supply, consulting and advisory services to healthcare organizations, hospitals, nursing homes, corporations and individuals. This strategy required the development of new services such as the recycling of paramedical devices and car rental.

Company 2 developed from high volume packaging production to high value added, 
custom-made goods. After the buy-out, the firm preferred to concentrate on the development of its 'one stop-one shop solution' packaging concept by leveraging synergies between the business units (folding cartons, flexible packaging and plastic packaging) in the group through cross-selling services. Two years after the MBO it developed partnerships with large international food firms to increase its production innovation capacity, indicating a shift from mere efficiency to a value added innovative focus.

Company 3 developed a strong competitive aggressiveness stance after the buy-out by offering low prices, as well as a customized focus (niche) in the carpet industry. It acquired firms in several European countries specialized in weaving techniques to develop further technology and increase market share. Post-MBO it launched CAD/CAM software to produce complex carpet design and software for use in other applications. Its other business unit is striving to become the market leader through partnerships that offer innovative solutions in geographic information systems for municipalities.

Company 4 , the bus manufacturer, shifted from a mass market approach to a 'customized focus' in manufacturing and selling buses. It established alliances with Canadian and US bus companies to serve the US market. The new owners increased the firm's customized focus on the use of technology, materials and fuel usage for their new product development and were successful in obtaining orders for subsidized bus manufacturing for underdeveloped countries.

Besides changes in the strategy content we observed changes in the process of strategy formulation. Post-MBO in Company 1 and 3 strategies were formulated by the management team and the Supervisory Board with representatives of the venture capitalists. Additional input for the strategy process in these companies comes from consumer councils and brainstorming sessions. In Company 2 this process takes place through customer oriented self-managing teams and in Company 4 through weekly meetings between the manager/owner and the six heads of departments. However, the strategy goals after the MBO remain the same in terms of target percentage increases in market share, divisional profit, competitiveness standards and market penetration.

\section{Beliefs systems}

Pre-MBO we found no beliefs systems in the sense of formal business philosophies relating to how to create value. Post-MBO these beliefs are formalized in a culture that stimulates intrapreneurship, supports customer focus and quality control orientation. In the 
cases studies we found a variety of organizational arrangements through which this was stimulated. In Company 1, regional meetings between the CEO and the managers from the dealer network were used to discuss how to anticipate opportunities and in what direction. An analysis of strengths and weaknesses of every manager was made in order to determine their training needs and the firm's replacement policy. During the regional 'soapbox' meetings the main core values that promote a business mind were: learning to work efficiently, stimulating a commercial attitude among salespersons and teaching physicians as fee earners to become more cost conscious in the post-MBO situation. In Company 2 the management was actively involved in communicating that product quality would be achieved by the way customers, suppliers and employees work together in continuous improvement projects. Self-managing teams consisting of technical and commercial people negotiated the contracts with customers. Company days, business trips and seminars were organized in Company 3 to stimulate the 'we-feeling' in an organization that is eager to learn from the ideas and experiences of its own people. The top manager stimulates the perception among his employees of a mutual adventure. Company 4, communicated its business values formally to its production managers, e.g. about flexible manufacturing and acceptable price-quality ratios using ISO-documents, to achieve competitive advantage. They use these documents during regularly planned team briefings of employees. All but the last firm used internal business magazines to support the communication of missions and credos and to inform people in the firm about current business developments.

\section{Boundary Systems}

The boundaries with regard to product markets and investment were much more clearly specified post-MBO. Before privatization, in Company 1 attention was not given to strengths or weaknesses of the firm, nor was any form of entrepreneurship promoted that involved risk-taking. After privatization a lot of time was invested in product innovation and in the exploration of the market, which resulted in the development of guidelines to approach a variety of customers. In this firm, the strategic domain developed after four to five years. This was demonstrated by divesting in 1998 aconsulting advisory service acquired in 1995 and at the same time starting activities like recycling of paramedical devices and car rental for the disabled.

In the other firms, boundaries were mainly found in guidelines such as return on investment targets and limitation to pre-selected product-market combinations, which were absent pre-MBO. In Company 2 the new shareholders were only willing to accept 
investments in the food sector, which comply with environmental rules which are expected to achieve ROI's above 20 percent. With 300 million consumers, Eastern Europe is an important target. Two loss-making companies were divested following the MBO because they lacked the potential to contribute profitably to specialist packaging services.

In Company 3 an indicator of greater risk taking following the $\mathrm{MBO}$ was the venture set up in the US. This was a very expensive lesson because this venture failed. After the failure of the start-up, the chief financial officer was given more authority to calculate the risks of the firm's strategic decisions. From then on, opportunities to expand in familiar niches were selected in Europe. After the buy-out, Company 3 acquired several companies to expand into the carpet and the printed textile market in the UK, France, Belgium and in its home market.

The size of the investment, the subsidy for manufacturing customised and environmental friendly buses and buses aimed at developing countries were the most important boundaries for Company 4. Initial costs were kept low because Company 4 focuses on opportunities within these boundaries, thus avoiding major leaps into new market segments.

\section{Diagnostic Control Systems}

Before privatization, a framework for diagnostic control in Company 1 was missing. Instruments for planning, cost control and performance measurement developed gradually following privatization. Initially, as part of the development of an entrepreneurial culture, control occurred on a more informal basis. After a couple of years the subsidiaries became profit centres and measured the success of managers in the beginning only by turnover targets. In practice this led to a severe 10 percent loss of personnel caused by heavy pressure by the management to reach turnover goals. Management focussed on the sales of wheelchairs because of the higher margins compared to the wheelchairs for hire. This was at the expense of the wheelchair rentals thus decreasing the chances for employees to satisfy customer needs, and causing caused higher costs of supplies. The Company was forced to differentiate its diagnostic systems in relation to performance evaluation from a single focus on turnover to a more balanced set of criteria. Achievement of the targets set for these criteria determines the flexible component in the reward structure of the managers. This is based on different weights comprising profit margin for 30 percent, accounts receivable, cost targets and stock control targets for 20 percent, and last but not least turnover targets 10 percent. 
Following the MBO in Company 2 the managing directors played more 'hands-on' roles than before, focusing on intensifying machine utilization and efficiency, lowering costs and increasing of capacity. After two years of restructuring, performance measurement based on critical success factors was extended to factors that support close working relationships between the firm and its industrial customers. This was implemented by appointing account management teams for several clients. For example, the firm uses electronic data interchange to integrate its planning system with the clients' planning systems, enabling more accurate scheduling of production and deliveries. Just in time delivery systems and other logistic support help minimize clients' inventories and ensure receipt of their packaging at short notice. As a result, 100 of the 140 employees participate after the MBO in the budget process in order to control costs, sales and profits.

In Company 3 and Company 4 the content of diagnostic controls have not changed. In Company 4 the bus manufacturing process is controlled by clear budget norms of labor and material based on long standing experience and by quality checks. However, in Company 3 the venture capitalist introduced a more refined way to report on cash flows at the product level.

Another change reported in both companies is the changing attitudes toward the use of control systems. Employees now experience the budgets as their own budget and thus their own costs and are thus more eager to take budgets decisions more seriously than before the buyout. Budgets are tailored to their own information needs rather than being enforced topdown by headquarters with unrealistic deadlines and targets. In general, top management is paying more attention to internal communication of information about turnover, prospective customers, orders and tenders.

\section{Interactive Control Systems}

Interactive control in Company 1 took place through the strategic appointment to the Supervisory Board of the chairman of the Dutch Council for the Disabled. Top management now receive up-to-date information from the political decision-making process on the deregulation of certain industries and on legislation with regard to individuals with a physical functional limitation. This enables management to detect and remove major strategic uncertainties for the firm. Another example is the establishment of a consumer council where on a regular basis the supply of products and services is discussed between the responsible managers and their customers. 
For Company 2 a serious threat is over-capacity. Trends that have become stronger after the MBO are: increasing responsibility for environmental friendly products, increasing buyer concentration and bargaining power and rapid, short-to-medium run volumes of specialized packaging. These changes required effective strategic response by increasing operating scale on an international basis, by being more receptive to requests for customization and by recognising the need to take account of environmental factors. The one-stop shop and supply chain concepts are triggers for the Company's proactive and innovative approaches to packaging. These help management prevent the risks of oversupply involved in this type of industry. In addition, they involve decentralized selfmanaging teams with seats on consumer panels who have the authority to make decisions concerning production, costs and prices. Quality management training programs are used to ensure that skills keep the same pace with technological and market developments. The firm is thus able to respond rapidly to latest consumer trends. These partnerships with large customers are used to establish a position of sustained growth and present a continual demand for additional capital investment. From certain levels approval by the board of commissioners is mandatory.

In Company 3 we found an explicit link between interactive and diagnostic control systems. The results from the brainstorming sessions in business units between management and personnel were used in budgets, thus highlighting the consequences for strategy and implementation. Before the MBO only the management team had discussions about the strategy and communicated the budgets top down to the departments. Post-MBO the directors supplied the employees with a list of priorities regarding the detection, analysis and exploration of business opportunities as well as the development of policy, e.g. selection of takeover targets and investment in technological applications for weaving and geographic information systems. There was more room for bottom-up communication and quick decision-making, resulting in a richer stream of business proposals with regard to acquisitions and equipment from the business units, thus stimulating autonomy regarding entrepreneurial initiatives.

In Company 4 interactive control takes place between top and middle management in weekly meetings to discuss issues such as the consequences of competitor actions, market trends and changes in subsidizing business for developing countries for the firm's strategy.

\section{CONCLUSIONS}

This paper has sought to analyze why and how management control systems are used 
in buy-outs to implement strategy change. The principal findings are as follows:

The Companies in this study show an increase in the market orientation of their strategies post-MBO. The new owners/managers are adapting their firms strategically through innovation, marketing and organization design to different market niches and contexts. These findings supplement the study of Jones (1992) where for the majority of companies the state of environmental dynamism was unaltered, thus enabling the companies to intensify the use of their existing accounting techniques of formal control such as budgets. In contrast, in the buy-outs examined here, there was a need to adopt new ways of coping with changes in strategy direction. The evidence from the four case studies supports the view of Wright et al. (2000), that managerial incentives in buy-out firms can foster imitation or strategic innovation after a period of neglect. The new owners are released from the investment constraints of the former parent company that blocked innovation and can carry out their own ideas on how to make profits.

In the Jones' study regular but less formal discussion of operational and policy matters took place only at the management level. No novel organisational control system emerged to provide additional information concerning the interface between external environments and internal operations. In our study, changes in the strategy formulating process were characterized by interactive controls. However, the frequency with which strategic information about competitors, products, politics and technology was analysed by management varied. Some firms use brainstorm sessions, others task teams and/or councils. Interactive control is typically used selectively to sustain revitalization and innovation strategies. These organizational arrangements are indicative of search and learning behaviour. Key personnel at different levels of these companies are involved in discussions with top management about strategic uncertainties relating to the intended strategy.

These finding are consistent with the characteristic that buy-outs bring management and ownership closer to each other and narrow the gap between strategy and implementation (Bruining, 1992). Before the buy-out there was a lack of regular exchange of strategically important information between subsidiary management and employees. This exchange, if present, was limited to the management of the parent company and the management of the subsidiary. This pattern changed after the MBO as the former subsidiary management has to delegate tasks and control to lower levels in the firm and be very clear about the future direction of the firm.

Management control goes beyond the management accounting systems in buy-outs 
where entrepreneurial opportunities exist. In addition to the existing formal controls, these companies use other management control techniques to match the changing environmental conditions. With the framework of the 'levers of control', practices are identified that reflect the choice of which management control activities are selected in cases where the companies want to add value to the business through new products/new market developments that were frustrated by the parent prior to the MBO.

One of the new controls is the increase in use of beliefs. The business philosophy regarding how to reach customers is formally communicated by management to employees in a variety of forms in all the companies. Affirmation is explicitly sought about the direction of the firm, its ambition and the essential capabilities and attitudes of its employees that stimulate entrepreneurship. Pre-MBO the respective parent companies did not develop initiatives to use these beliefs systems explicitly.

The Jones study focused on existing ACS as a channel for effecting changes in organizational culture, e.g. managerial philosophies to promote participation in budgets. Participation was not extended beyond middle managers, which contrasts with the apparently more entrepreneurial oriented leadership style used by top managers in our case studies. We see the reported increase in use of beliefs in our study as a move towards improved matching of an entrepreneurial culture with the organizational context, where financial risks increase after becoming an independent company.

This finding is consistent with the buy-out literature (Green, 1992; Zahra, 1995; Wright et al., 2000; Bruining and Wright, 2002) that highlights new owner-managers with high levels of commitment eager to implement growth oriented strategies to use the upside potential of the firm. These organizations are characterized by an entrepreneurial driven culture that encourages initiatives by its employees to detect profitable opportunities.

If boundaries are lacking (as in Company 1) before the buy-out, top management gradually set standards for investment volumes, return ratios and for well-defined markets. From the beginning in all but Company 1, the selection of market niches and minimum return on investments are the most cited boundaries. Within the new boundaries the employees and managers are free to generate proposals. This is in sharp contrast with the Jones' study, where no messages concerning the prevalent markets for the firm and conducts for human behavior were transmitted through the established ACS. This is probably due to the lesser need to exchange information about strategy and how to achieve it. 
The finding of renewed boundaries is consistent with the delegation of decisionmaking to lower levels in the organization. Decrease in size and complexity of the organizational structure stimulate decentralization after buyout (Phan and Hill, 1995) and top managers experience more immediate freedom and independence, which enables more flexible decision-making and delegation.

Before the MBO the employees of the companies experience diagnostic control systems as distant, not realistic, not tailor made to own information needs and top-down enforced. This changes post-MBO. Freedom from conformity with the practices of the former parent resulted in management control activities being more closely matched with organizational contexts. Some companies, at the request of the venture capitalist, take finetuning measures to supplement the monitoring on cash flows and contribution to profit on a product basis. Managers and employees attach more importance to traditional accounting measures. The involvement of employees in the materialization of budgets increases, as well as their experience to perceive budgets as an important navigation tool. The planning takes place more accurately. Employees and managers develop information systems that are more appropriate to their needs. A major difference with regard to the budgeting processes is the shift from top-down to bottom-up budgeting.

This finding is supported by Jones (1992) on buy-outs and also by Mitchell et al. (1997) for venture capital investments generally. Jones found that planning systems became more meaningful, were connected to real strategy and were part of the routines. Changes in attitudes towards management control were associated with and facilitated by managerial philosophies, which extended informal control, through participation, as well as formal control through documentation and meetings. Removing barriers between management and workers is seen as necessary to prepare budgets with more commitment and reality. The diagnostic control levers such as budget systems remain the same after the buy-out, because parent companies have subsidiaries with well-developed information systems. Operational controls were altered least.

Overall we conclude that this study revealed coherence between a change in strategy and the application of levers of control. Explicitness of strategy content and strategy formulation appears to be positively related to the intensity with which the levers are used separately and together for implementation. Before buy-out, companies tend to be less entrepreneurial, because the parent companies do not consider them as core business and exclude them from financial resources. Managers and employees in the pre-buy-out 
situation are not very well informed about the future direction of the company as a subsidiary, and this makes them more reluctant to search for new opportunities. Our case studies indicate that growth buy-outs enhance the positive stance taken to entrepreneurship by their new owners/managers. They initiate more entrepreneurial activities, which in turn make the management and employees eager to search and focus on certain opportunities as well as to learning. The coherence of management control and management accounting systems, lacking pre-buy-out developed incrementally post buy-out. We see the use of hitherto neglected or ignored control mechanisms as an additional capacity to strategy implementation and formulation and as a valuable extension of the diagnostic control systems post-MBO. 


\section{REFERENCES}

Alchian, A.A. and Demsetz, H., 1972. Production, information costs, and economic organisation, American Economic Review, 2,777-795.

Atkinson, A.A. and Balakrishnan, R., Booth, R.P., Cote, J.M., Groot, T., Malmi, T., Roberts, H., Uliana, E., Wu, A., 1997. New Directions in Management Accounting Research, Journal of Management Accounting Research, 9, 79-108.

Bruining, J., 1992. Performance Improvement after Management Buy-Out, unpublished phd Erasmus University Rotterdam.

Bruining, J., Wright, M., 2002. Entrepreneurial orientation in management buy-outs and the contribution of venture capital, Venture Capital: An International journal of entrepreneurial finance, June, 4, 2, 147-168.

Burchell, S., Clubb, C., Hopwood, A. and Hughes, A., 1980. The roles of accounting in organisations and society. Accounting Organisations and Society, 5, 5-27.

Burt, R.S., 1992. The Social Structure of Competition, in N. Nohria and R.G.Eccles (eds): Network and organisations: Structure, Form and Action, Boston: Harvard Business School Press.

CMBOR, 2001 and 2002. Quarterly Review from The Center for Management Buy-out Research, Nottingham University Business School.

Cohen, W.M., and Levinthal, D.A., 1990. Absorptive capacity: A New Perspective on learning and Innovation, Administrative Science Quarterly, 35, 128-52.

Cyert, R.M., and March, J.G., 1963. A Behavioral Theory of the Firm. Englewood Cliffs, N.J., Prentice Hall.

European Private Equity and Venture Capital Association (EVCA) 2001. Survey of the economic and social impact of management buy-outs and buy-ins in Europe, Research paper, Zaventum, Belgium

Eisenhardt, K.M., 1989. Building theories from Company study research, Academy of Management Review, 14, 532-550.

Green, S., 1992. The impact of ownership and capital structure on managerial motivation and strategy in management buy-outs: A Cultural Analysis, Journal of Management Studies, 4, 513-535.

Jensen, M.C., 1989. Eclipse of the public corporation. Harvard Business Review, 67, 6174.

Jensen, M.C., 1993. The modern industrial revolution, exit and the failure of internal control systems, Journal of Finance, 48, 831-80

Jones, C.S., 1992, The attitudes of owner-managers towards accounting control systems following management buy-out, Accounting, Organizations and Society, 17, 151-168.

Kaplan, S.N., 1989. The Effects of Management Buyouts on Operating Performance and Value. Journal of Financial Economics, 24, 217-254. 
Keating, P.J. 1995. A Framework for Classifying and Evaluating the Theoretical Contributions of Case Research in Management Accounting. Journal of Management Accounting Research, 7, 66-86 Fall 1995.

Langfield, K., 1997. Management control systems and strategy: a critical review. Accounting, Organizations and Society, 22, 207-232.

Merchant, K.A., 1985. Control in Business Organisations. Marshfield, Mass., Pitman.

Mintzberg, H., 1979. The Structuring Of Organisations. Englewood Cliffs, NJ.,Prentice Hall.

Mitchell, F., Reid, G. and Terry, N., 1997. Venture capital supply and accounting information system development, Entrepreneurship Theory and Practice, 21, 45-62.

Otley, D., 1999. Performance Management: a Framework for Management Control Systems Research, Management Accounting Research, 10, 363-382

Ouchi, W.G., 1977. The Relationship Between Organisational Structure and Organisational Control., Administrative Science Quarterly, 22, 95-113.

Phan, P. and Hill, C., 1995. Organizational restructuring and economic performance in leveraged buyouts: An ex post study, Academy of Management Journal, 38, $704-739$.

Reid, G.C., 1996, Fast growing small entrepreneurial firms and their venture capital backers: an applied principal-agent analysis, Small Business Economics, 8, 1-14.

Robbie, K. and Wright, M., 1995. Managerial and ownership succession and corporate restructuring: Company of management buy-ins. Journal of Management Studies , 32, $527-$ 550 .

Robbie, K. and Wright, M., 1996. Management buy-ins: entrepreneurship, active investors and corporate restructuring, MUP, Manchester.

Simons, R. 1995., Levers of Control: How Managers Use Innovative Control Systems to Drive Strategic Renewal, Harvard Business School.

Speklé, R.F., 2001. Explaining management control structure variety: a transaction cost economic perspective, Accounting, Organizations and Society, 26, 419-441

Teece, D.J., Pisano, G., and Shuen, A., 1997. Dynamic Capabilities and Strategic Management, Strategic Management Journal, 18, 7, 509-33

Volberda, H.W., 1998. Building The Flexible Firm, Oxford: Oxford University Press.

Westley, F.R., 1990. Middle Managers and Strategy: Microdynamics of Inclusion, Strategic Management Journal, 10, -32.

Wright, M., and Coyne, J., 1985. Management buy-outs, Croom Helm, London.

Wright, M., Robbie, K., Thompson, S., and Starkey, K., 1994. Longevity and the life cycle of MBOs, Strategic Management Journal, 15, 215-27

Wright, M., Hoskisson, R.E., Busenitz, L.W. and Dial, J., 2000. Entrepreneurial growth through privatization: the upside of management buyouts, The Academy of Management Review , 25, 3, 1-601 
Wright, M., Hoskisson, R.E. and Busenitz, L.W., 2001. Firm rebirth: Buyouts as facilitators of strategic growth and entrepreneurship, The Academy of Management Executive ,15, 111-125.

Zahra, S.A., 1995. Corporate entrepreneurship and financial performance: the case of management leveraged buyouts, Journal of Business Venturing ,10, 225-247. 
Appendix 1: Interview about strategy and control levers pre- and post-MBO in retrospective

\section{General}

-background of the interviewee

-role of the interviewee held within the firm

-changes in the role post-MBO?

-history of the firm

-general information about core products and organization

-general information about industry, market- and technology development

-external shareholders/financiers

\section{Strategy}

-reason for the MBO

-underlying strategic goals

-vision on management

-strategy content

-strategy process

-effectiveness strategy

-adaptations strategy

\section{beliefs systems}

-presence of shared vision

-use of missions, vision, credos

-does it affect the your role in any way

-involvement employees/management

-is there a cultural change program?

-relationship shared vision and new opportunities

\section{boundary systems}

-boundaries for the firm in seeking chances and opportunities

-the risks avoided?

-operating rules/behavioural codes managers

-sanctions for opportunity seeking behavior

\section{diagnostic control systems}

-firm's key performance indicators

-critical success factors; responsibilities

-involvement with translation strategy in budgets

-are any changes made? Reasons?

-standards, output measures, incentives budgets

-role of monitoring performance

-fine-tuning budgets post mbo

-monitoring role of external shareholders

-frequency of budget adaptations

-attention and attitudes employees towards budget

-information needs and current performance measures

\section{interactive control systems}

-nature involvement employees non-routine decisions

-experiments, knowledge systems, management development, learning 
-items from operations on strategic agenda top management

-frequency attention to budgets from all managementlevels

-frequency of discussion strategic items between management levels

-changes in assumptions of firm's strategy 


\section{Appendix 2: Company synopses}

\section{Company 1}

The firm is a supplier of paramedical advice, orthopedic and rehabilitation products to individuals with a physical functional limitation for lodging, working and living. Till 1994 it functioned as a public municipal medical service as part of the law on municipal administrative office. After 1994 this public service agency with 240 employees was privatized and took care for service contracts for disabled persons with local authorities on a decentralized level in competition with other companies. After privatization it introduced a wheelchair renting system that lowered the costs with 20 percent and led to 25 percent savings on the budgets for the municipalities. Next to being price competitive the firm kept on improving service levels and developing new orthopedic products for the customer in order to grow autonomously. The firm created an own dealers network, and acquired a care products firm, with dfl $60 \mathrm{mn}$ and 240 employees. In 1997 turnover amounted fl $290 \mathrm{mn}$ with 1000 fte's. New shareholders were the management (4.5\%), Alpinvest and Parcom (each $40 \%$ ) and Residentie Venture Beheer (15\%). A foundation has a small percentage of shares under trust for the employees of the firm.

\section{Company 2}

In 1994 the firm was sold by a state owned Austrian Company in a management buy-out to its directors. Price dumping forced the parent Company to divest its subsidiary. A division of the buy-out firm with 140 employees, manufactures synthetic packaging for the consumer market in the food sector and has three business units. One for diary products, another develops and produces packaging concepts for convenience goods and the third is specialized in wholesale and large-scale business. These business units are responsible for product development, planning and production as well as for marketing, sales and supply. CVC Capital and Parcom Ventures has each a $40 \%$ stake in the equity, whereas the rest of the shares are in the hands of top management and 15 middle managers. After the first years of improving efficiency and using synergies between the business units to create a one-stop shop, the firm developed into a specialist in packaging solutions on the basis of long-term partnership with consumer brand multinationals. It specializes to provide a wide range of specialist packaging services and packaging concepts that demand high speed, capacity imagination and innovation. Innovation in the plastics division is e.g. a high barrier packaging which keeps fruit fresh and allows customers to see the product. The folding cartons division developed for its client an easy opening facility

\section{Company 3}

The firm is a manufacturer of Computer Aided Design (CAD) and Computer Aided Manufacturing (CAM) systems and creates one-stop solutions for the carpet industry, printed textiles and woven fabrics industries. After the buy-out it started gradually to invest in developing, manufacturing and marketing dedicated software and services for textile design, colourmatching, color separation, fabric simulation, 3D presentation and production of textiles. It launched a new CAD/CAM software Tuft/NT to produce complex carpet designs and reduced production time from initial to final stage. Besides these systems it is also a producer of Geographic Information Systems for municipalities. With headquarters based in The Netherlands, offices in the UK, France and the US with a worldwide agent network, the firm positions itself to market and sell its products on a worldwide scale. Turnover amounts Dfl $13 \mathrm{mn}$ of which $70 \%$ is exported. Gilde Investment owns a minority stake of $36 \%$. Top management and 20 employees hold a majority stake of $64 \%$. The firm was bought for an undisclosed sum from receivership of HCS Technology, which went bankrupt in 1992. 


\section{Company 4}

In the late eighties this bus manufacturer merged with three competitors into one Company United Bus. This new combination did not last long because of the increased competition by new entrants on the bus replacement market and the privatization of regional transport in Europe that cancelled the subsidy arrangements for bus companies. In 1993 United Bus went into receivership and the former owners bought the firm back in a management buyin. The official receivers preferred the former family owners of the firm above industrial buyers because they are better informed about the industry and guaranteed employment of 180 people. The new owners increased the firm's customized focus on the use of technology, materials and fuel usage for their new product development and were successful to get orders for subsidized busmanufacturing for underdeveloped countries. 


\section{Appendix 3: Summary of findings}

\begin{tabular}{|c|c|c|c|c|}
\hline & Case 1: privatization & Case 2: mainbo & Case 3: mbo & Case 4: mbi \\
\hline $\begin{array}{l}\text { Company } \\
\text { Strategy } \\
\text {-content }\end{array}$ & $\begin{array}{l}\text { Products physical } \\
\text { handicapped } \\
\text { from monopolist to market } \\
\text { oriented advice, products, } \\
\text { distribution } \\
25 \% \text { market share } \\
\text { post buy-out governance } \\
\text { with venture capitalist and } \\
\text { management team }\end{array}$ & $\begin{array}{l}\text { Packaging } \\
\text { from volume to 'one- } \\
\text { stop-shopping'/ tailor- } \\
\text { made solutions buyers } \\
\text { every subsidiary } \\
\text { competitive and } \\
\text { profitable } \\
\text { delayering firm, self } \\
\text { managing customer- } \\
\text { oriented teams }\end{array}$ & $\begin{array}{l}\text { Software textile } \\
\text { manufacturer } \\
\text { from price to } \\
\text { price/quality and } \\
\text { acquisitions } \\
\text { market leader niches, } \\
\text { partnerships suppliers } \\
\text { and shop solutions } \\
\text { post buy-out } \\
\text { governance with } \\
\text { venture capitalist and } \\
\text { and personnel }\end{array}$ & $\begin{array}{l}\text { Bus manufacturer } \\
\text { price vs. } \\
\text { differentiation } \\
\text { markets } \\
\text { increase market } \\
\text { share, market- } \\
\text { penetration } \\
\text { manager/owner } \\
\text { and six division } \\
\text { managers }\end{array}$ \\
\hline Beliefs & $\begin{array}{l}\text { from passive to active } \\
\text { solution seeking } \\
\text { from no corporate } \\
\text { entrepreneurship to intra- } \\
\text { preneuring }\end{array}$ & $\begin{array}{l}\text { From passive to active } \\
\text { attention to quality } \\
\text { and customer } \\
\text { orientation through } \\
\text { mission }\end{array}$ & $\begin{array}{l}\text { from meaningless to } \\
\text { meaningful mission } \\
\text { shared vision, } \\
\text { Company days, } \\
\text { enforcement 'we- } \\
\text { feeling' }\end{array}$ & $\begin{array}{l}\text { Communication } \\
\text { mission by ISO- } \\
\text { documents to } \\
\text { employees: identi- } \\
\text { fication, } \\
\text { acceptable price- } \\
\text { quality relation }\end{array}$ \\
\hline Boundaries & $\begin{array}{l}\text { from job descriptions to } \\
\text { guidelines to approach a } \\
\text { variety of customers by new } \\
\text { product- development }\end{array}$ & $\begin{array}{l}\text { from no selection to } \\
\text { delineating products } \\
\text { and markets: only } \\
\text { food sector which } \\
\text { comply to } \\
\text { environmental rules } \\
\text { Minimum ROIs }\end{array}$ & $\begin{array}{l}\text { selection of two } \\
\text { product-market- } \\
\text { combinations: carpet } \\
\text { and printed textile } \\
\text { market \& geographic } \\
\text { information systems } \\
\text { for municipalities }\end{array}$ & $\begin{array}{l}\text { concentration on } \\
\text { active utilization } \\
\text { of subsidies for } \\
\text { existing markets: } \\
\text { underdeveloped } \\
\text { countries \& } \\
\text { customized } \\
\text { environmental } \\
\text { friendly busses }\end{array}$ \\
\hline $\begin{array}{l}\text { Diagnostic } \\
\text { Controls }\end{array}$ & $\begin{array}{l}\text { post buy-out: responsibility } \\
\text { accounting with appropriate } \\
\text { accounting measures } \\
\text { developing overtime }\end{array}$ & $\begin{array}{l}\text { from targets figures } \\
\text { on division level, to } \\
\text { contracts per team. } \\
\text { budgets and personal } \\
\text { setting of tasks; } \\
\text { just in time delivery; }\end{array}$ & $\begin{array}{l}\text { format budgetsystems } \\
\text { unchanged; VC's fine- } \\
\text { tuning of CFL; after } \\
\text { buyout more } \\
\text { importance attached } \\
\text { to conscious } \\
\text { consideration and } \\
\text { feedback. }\end{array}$ & $\begin{array}{l}\text { format budget- } \\
\text { systems unchan- } \\
\text { ged; after buyout } \\
\text { more top-down- } \\
\text { bottom-up } \\
\text { process; clearer } \\
\text { responsibilities; } \\
\text { quality checklists }\end{array}$ \\
\hline $\begin{array}{l}\text { Interactive } \\
\text { Controls }\end{array}$ & $\begin{array}{l}\text { interactive control mainly } \\
\text { between top management } \\
\text { and venture capitalists; } \\
\text { creating learning } \\
\text { organization through } \\
\text { soapbox, recurrent } \\
\text { consultation employees and } \\
\text { customers. }\end{array}$ & $\begin{array}{l}\text { consultation about: } \\
\text {-transfer new } \\
\text { production with } \\
\text { reference to new } \\
\text { legislation; } \\
\text {-synergy between } \\
\text { subsidiaries. }\end{array}$ & $\begin{array}{l}\text { brainstorming in BU's } \\
\text { about future direction, } \\
\text { encouraging bottom } \\
\text { up initiatives by the } \\
\text { directors. }\end{array}$ & $\begin{array}{l}\text { pre-mbi no inter- } \\
\text { active control; } \\
\text { post mbi weekly } \\
\text { consultations } \\
\text { about changes in } \\
\text { competitive } \\
\text { actions and } \\
\text { impact of trends } \\
\text { on the strategy }\end{array}$ \\
\hline
\end{tabular}




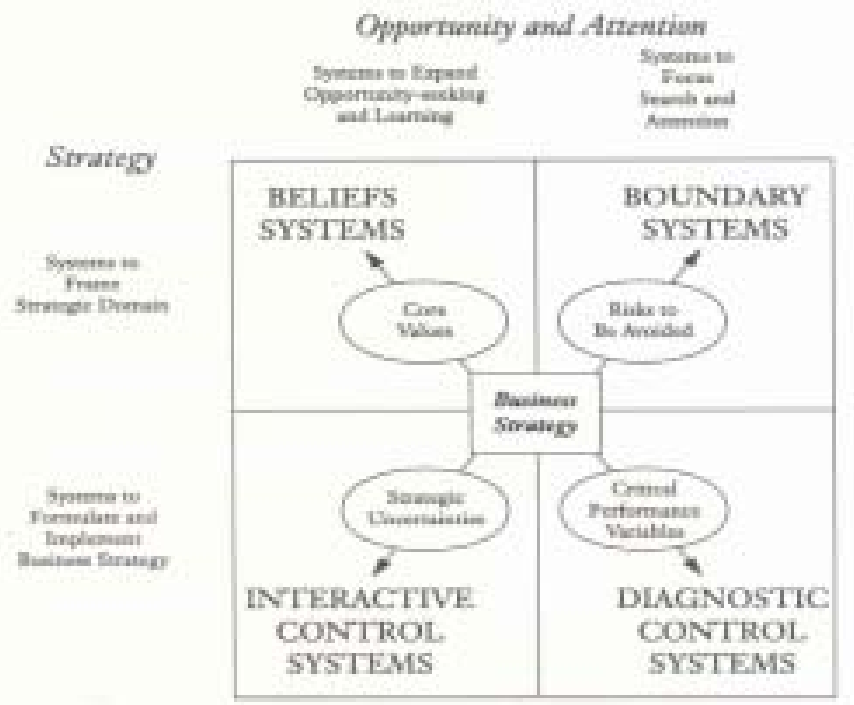

Figure 1:Interrelation levers of control with strategy, opportunity, and attention (Simons 1995, 157 
Table 1: Number and Total Value ( $€$ mn) of Buy-outs in the Netherlands (1991-2001)

\begin{tabular}{|l|l|l|l|l|l|l|l|l|l|l|l|}
\hline Year & $\mathbf{1 9 9 1}$ & $\mathbf{1 9 9 2}$ & $\mathbf{1 9 9 3}$ & $\mathbf{1 9 9 4}$ & $\mathbf{1 9 9 5}$ & $\mathbf{1 9 9 6}$ & $\mathbf{1 9 9 7}$ & $\mathbf{1 9 9 8}$ & $\mathbf{1 9 9 9}$ & $\mathbf{2 0 0 0}$ & $\mathbf{2 0 0 1}$ \\
\hline NR & 44 & 50 & 55 & 41 & 57 & 56 & 61 & 69 & 42 & 75 & 54 \\
\hline $\boldsymbol{€}$ & 594 & 446 & 579 & 1258 & 856 & 1030 & 1082 & 3457 & 4463 & 1785 & 4339 \\
\hline
\end{tabular}

Source: Centre for Management Buy-Out Research (CMBOR) 


\section{Publications in the ERIM Report Series Research* in Management}

ERIM Research Program: "Organizing for Performance"

\section{2}

Trust and Formal Control in Interorganizational Relationships Rosalinde Klein Woolthuis, Bas Hillebrand \& Bart Nooteboom ERS-2002-13-ORG

Entrepreneurship in China: institutions, organisational idendity and survival. Empirical results from two provinces. Barbara Krug \& Hans Hendrischke ERS-2002-14-ORG

Managing Interactions between Technological and Stylistic Innovation in the Media Industries. Insights from the Introduction of eBook Technology in the Publishing Industry

Tanja S. Schweizer

ERS-2002-16-ORG

Investment Appraisal Process in the Banking \& Finance Industry

Mehari Mekonnen Akalu \& Rodney Turner

ERS-2002-17-ORG

A Balanced Theory of Sourcing, Collaboration and Networks

Bart Nooteboom

ERS-2002-24-ORG

Governance and Competence: How can they be combined?

Bart Nooteboom

ERS-2002-25-ORG

ISO 9000 series certification over time: What have we learnt?

Ton van der Wiele \& Alan Brown

ERS-2002-30-ORG

Measures of Pleasures: Cross-Cultural Studies and the European Integration

Slawomir Magala

ERS-2002-32-ORG

Adding Shareholders Value through Project Performance Measurement, Monitoring \& Control: A critical review Mehari Mekonnen Akalu \& Rodney Turner

ERS-2002-38-ORG

Web based organizing and the management of human resources

Jaap Paauwe, Rolf Visser \& Roger Williams

ERS-2002-39-ORG

* A complete overview of the ERIM Report Series Research in Management:

http://www.ers.erim.eur.nl

ERIM Research Programs:

LIS Business Processes, Logistics and Information Systems

ORG Organizing for Performance

MKT Marketing

F\&A Finance and Accounting

STR Strategy and Entrepreneurship 
Challenging (Strategic) Human Resource Management Theory: Integration of Resource-based Approaches and New Institutionalism

Jaap Paauwe \& Paul Boselie

ERS-2002-40-ORG

Human Resource Management, Institutionalisation and Organisational Performance: a Comparison of Hospitals, Hotels and Local Government

Paul Boselie, Jaap Paauwe \& Ray Richardson

ERS-2002-41-ORG

The added value of corporate brands: when do organizational associations affect product evaluations?

Guido Berens, Cees B.M. van Riel \& Gerrit H. van Bruggen

ERS-2002-43-ORG

High Performance Work Systems: "Research on Research" and the Stability of Factors over Time Paul Boselie \& Ton van der Wiele

ERS-2002-44-ORG

Diversification and Corporate Governance

George W. Hendrikse \& Aswin A..C..J. Van Oijen

ERS-2002-48-ORG

Governance Structure, Product Diversification, and Performance

Aswin A. Van Oijen \& George W. Hendrikse

ERS-2002-51-ORG

Global Sourcing: Fad or Fact?

Michael J. Mol, Rob J.M. van Tulder, Paul R. Beije

ERS-2002-55-ORG

Internationalization Of Management Buyouts: Firm Strategies And Venture Capitalist Contribution Mike Wright, Andy Lockett, Paul Westhead, Hans Bruining

ERS-2002-58-ORG

The Importance Of Customer Satisfaction In Organisational Transformation: A Case Of A Dutch Temporary

Employment Agency

Martijn Hesselink, Ton van der Wiele and Paul Boselie

ERS-2002-60-ORG

A Study On The Applicability Of SERVQUAL Dimensions For Web Sites

Jos van Iwaarden, Ton van der Wiele

ERS-2002-61-ORG

Entrepreneurial Orientation In Management Buy-Outs And The Contribution Of Venture Capital

Hans Bruining and Mike Wright

ERS-2002-67-ORG

The odd role of proximity in knowledge relations - High-tech in The Netherlands

Gerben van der Panne, Wilfred Dolfsma

ERS-2002-75-ORG

Organizing as Improvisations (Methodological Temptations of Social Constructivism)

S. Magala

ERS-2002-76-ORG

Best Practice in Company Standardisation

Florens J.C. Slob, Henk J. de Vries

ERS-2002-81-ORG 
Standardisation education

Henk J. de Vries

ERS-2002-82-ORG

Elective Identities

(Culture, Identization And Integration)

Slawomir J. Magala

ERS-2002-92-ORG

Technology Push, Demand Pull And The Shaping Of Technological Paradigms -

Patterns In The Development Of Computing Technology

Jan van den Ende \& Wilfred Dolfsma

ERS-2002-93-ORG

Modes of governance of new service development for mobile networks.

A life cycle perspective

Jan van den Ende

ERS-2002-94-ORG

The Development Of Mutual Trust In British Workplaces Through 'Partnership': Conceptualisations, Definitions And Experiences.

Graham Dietz

ERS-2002-97-ORG

Why Do European Venture Capital Companies Syndicate?

Sophie Manigart, Andy Lockett, Miguel Meuleman, Mike Wright, Hans Landström, Hans Bruining, Philippe Desbrières, Ulrich Hommel

ERS-2002-98-ORG

Management Control Systems and Strategy Change in Buyouts

Hans Bruining, Marcel Bonnet, Mike Wright

ERS-2002-113-ORG 